\title{
DEVELOPMENT OF ISLAMIC VALUES CIVICS MODULE ON RIGHTS AND OBLIGATIONS FOR ELEMENTARY HIGH SCHOOL STUDENTS
}

\author{
Melyani Sari Sitepu ${ }^{1}$, Chairunnisa Amelia ${ }^{2}$ \\ ${ }^{1,2}$ Fakultas Keguruan dan Ilmu Pendidikan Universitas Muhammadiyah Sumatera Utara \\ melyanisari@umsu.ac.id
}

Received: 23-07-2021

Revised: 11-09-2021

Accepted: 30-10-2021

\begin{abstract}
This article aims to develop a Civics module with Islamic values on the rights and obligations of high school students in elementary schools. This research is a development research $(\mathrm{R} \& \mathrm{D})$. This research uses a development research model. The steps in this research are: (1) potential and problems, (2) data collection, (3) product design, (4) module validation, (5) module design revision, (6) limited module trial, (7) Revision of modules, (8) The final product of the Civics module has Islamic values that meet the valid and practical criteria. The development process includes product design and product validation. Data collection techniques used in this study were observation and questionnaires. The results of this study indicate that the PPKn module has Islamic value. The material of rights and obligations developed has met the very valid criteria. This is evidenced by the average results of expert validation of $96 \%$ and $90 \%$ with very valid criteria. The PPKn module has Islamic values. The material of Rights and Obligations developed has met the practical criteria. This is evidenced by the results of the questionnaire from the small group trial. The score is $86.34 \%$ with very practical criteria.
\end{abstract}

Keywords: Citizenship Material Module, Islamic Values, Rights and Obligations Material, Elementary School

\section{Abstrak}

Artikel ini bertujuan untuk mengembangkan modul PPKn bernilai Islami materi hak dan kewajibanpada siswa kelas tinggi di Sekolah Dasar. Penelitian ini merupakan penelitian Pengembangan (R\&D) Penelitian ini menggunakan model penelitian pengembangan. Langkahlangkah dalam penelitian ini yaitu: (1) Poteensi dan masalab, (2) Pengumpulan data, (3) Desain produk, (4) Validasi modul, (5) Revisi desain modul, (6) Uji coba modul terbatas, (7) Revisi modul, (8) Produk akbir modul PPKn bernilai islami yang memenubi kriteria valid dan praktis. Proses pengembangan meliputi desain produk dan validasi produk. Teknik. pengumpulan data yang digunakan dalam penelitian ini adalah observasi dan Angket. Hasil penelitian ini menunjukan bahawa modul PPKn bernilai Islami Materi hak dan kewajiban yang dikembangkan telah memenubi kriteria sangat valid. Hal ini dibuktikan dengan hasil rata-rata validasi abli sebesar 96\% dan 90\% dengan kriteria sangat valid. Modul PPKn bernilai Islami Materi Hak dan Kewajiban yang dikembangkan telah memenubi kriteria praktis. Hal ini dibuktikan dengan hasil kuesioner dari ujicoba kelompok. kecil. Perolehan nilai sebesar 86,34\% dengan kriteria sangat praktis. Dari perolehan uji coba kelompok kecil disimpulkan babwa modul yang dikembangkean sangat valid dan praktis.

Keywords: Modul Materi Kewarganegaraan, Nilai Islam, Materi Hak dan Kewajiban, Sekolah Dasar 


\section{INTRODUCTION}

Education plays an important role in preparing quality human resources to obtain better results. The function of education is to guide students towards a goal that we value highly, namely to educate the nation's life and develop Indonesian people as a whole ${ }^{1}$. A good education is a successful endeavor to bring all students to that goal. What is taught should be fully understood by all students ${ }^{2}$. Education is also an effort of the community and nation in preparing its young generation for the sustainability of the life of the community and the nation for a better future ${ }^{3}$. Therefore, education should be managed, both in quantity and quality. This can be achieved if students learn according to the curriculum and get good learning outcomes ${ }^{4}$. This is in accordance with the context of National education as stated in Law no. 20 of 2003 concerning the national education system which outlines that "Education is a conscious and planned effort to create a learning atmosphere and learning process so that students actively develop their potential to have religious spiritual strength, self-control, personality, intelligence, noble character, and skills that needed by bimself, the community, the nation and the State".

From this statement, it can be concluded that education is a conscious effort to develop the potential of human resources who have spiritual intelligence and have noble character and skills in life in society, both locally, regionally and nationally. Based on article 14 of Law no. 20 of 2003, it is stated that the level of formal education consists of basic education, secondary education, and higher education. As for basic education, it is regulated in Law No. 20 of 2003 article 17, Basic education is the level of education that underlies the secondary education level. Education in elementary schools has a target of compulsory subjects, namely Indonesian language, mathematics, science, social studies, Civics, cultural arts and mulok ${ }^{5}$.

The targets for compulsory subjects in elementary schools are outlined in the curriculum. The curriculum in elementary schools in Central Helvetia District is the 2013 curriculum (K13). The 2013 curriculum is the development of the Education Unit Level Curriculum $(\mathrm{KTSP})^{6}$. In the 2013 curriculum, learning is carried out using themes to link

${ }^{1}$ Fatmah Almoayad dkk., "Health Professional Students' Perceptions and Experiences of Remote Learning During the COVID-19 Pandemic," International Journal of Learning, Teaching and Educational Research 19, no. 8 (30 September 2020), http://www.ijlter.org/index.php/ijlter/article/view/2621; A. Rusdiana, Konsep Inovasi Pembelajaran (Bandung: Pustaka Setia, 2014).

2 S. Nasution, Berbagai pendekatan dalam proses belajar dan mengajar (Jakarta: PT. Bina Aksara, 2011); Hayward P. Andres, "Active teaching to manage course difficulty and learning motivation," Journal of Further and Higher Education 43, no. 2 (7 Februari 2019): 220-35, https://doi.org/10.1080/0309877X.2017.1357073.

3 Akrim.2021.Strategi Peningkatan Daya Minat Belajar Siswa .Yogyakarta: Pustaka Ilmu

${ }^{4}$ Mhd Reza Fahlevi, Asnil Aidah Ritonga, dan Wahyuddin Nur Nasution, "The Relevance of The Madrasah Aliyah Fiqh Package Book Published By The Indonesian Ministry of Religion With The 2013 Curriculum," Ną̧hruna: Jurnal Pendidikan Islam 4, no. 2 (19 Agustus 2021): 460-76, https://doi.org/10.31538/nzh.v4i2.1605; Rony dan Siti Ainun Jariyah, "Urgensi Pendidikan Karakter Dalam Membentuk Akhlak Peserta Didik," Tafkir: Interdisciplinary Journal of Islamic Education 1, no. 1 (2020): 79-100, https://doi.org/10.31538/tijie.v1i1.18.

${ }^{5}$ Nilda Nilda, Hifza Hifza, dan Ubabuddin Ubabuddin, "Peran Kepala Sekolah Sebagai Supervisor Dalam Meningkatkan Kinerja Guru Pendidikan Agama Islam Sekolah Dasar," Attadrib: Jurnal Pendidikan Guru Madrasah Ibtidaiyah 3, no. 1 (25 April 2020): 12-18, https://jurnal.staidagresik.ac.id/index.php/attadrib/article/view/160.

${ }^{6}$ Hermino Agustinus, Manajemen Kurikulum Berbasis Karakter: Konsep, Pendekatan dan Aplikasi (Bandung: Alfabeta, 2014); Bahrissalim Bahrissalim dan Fauzan Fauzan, "Evaluasi Kurikulum Pelatihan Dalam Meningkatkan Kompetensi Pedagogik Guru Pai Di Balai Diklat Keagamaan Jakarta," Edukasia: Jurnal Penelitian Pendidikan Islam 13, no. 1 (25 Juli 2018): 25-52, https://doi.org/10.21043/edukasia.v13i1.2779. 
several subjects so that they can provide meaningful experiences for students. The learning system is based on integrative thematics ${ }^{7}$.

Citizenship Education ( $\mathrm{PKn})$ is one of the subjects integrated in thematic learning. Civics is a subject that is used as a vehicle to develop and preserve noble and moral values rooted in the culture of the Indonesian nation. Civics learning in elementary schools is intended as a teaching and learning process in order to help students learn well and shape Indonesian people as a whole in shaping the nation's character which is expected to lead to the creation of a society that places democracy in the life of the nation and state based on Pancasila, the Constitution and the Constitution. norms prevailing in society ${ }^{8}$. Citizenship Education is a subject that has specific characteristics in terms of its orientation to shape students' personalities so that they become good citizens who have a high understanding, appreciation and awareness of their rights and obligations and are able and capable of implementing them in everyday life in all fields. life based on the principle of proportionality, religious spirituality values, socio-cultural plurality values, cultural values, and the values of national unity and integrity.

In order to achieve the goal of fulfilling core competence 1, namely religion, and religious spiritual values, continuous efforts are needed, including the implementation of Civics education in elementary schools. One effort that can be done is to integrate Civics education in elementary schools with Islamic values. The application of the integration of Civics education with Islam is one manifestation of the unity of science. The paradigm of unity of science is not a new paradigm. This paradigm has been practiced by classical Muslim scientists such as Ibn Sina (980-1037 AD), Al Kindi (801-870 AD), and Al Farabi (874-950 $\mathrm{AD})^{9}$.

The Qur'an does not distinguish between religious sciences (Islam) and general sciences (technological science and social humanities), both religious and general sciences cannot be separated from each other ${ }^{10}$. In essence, all knowledge comes from Allah SWT. According to Islam, the education curriculum must be based on Islamic faith. That is, creed becomes the benchmark and standard of assessment of whether science can be studied or not, what is in accordance with Islamic creed may be studied, while those that are contradictory should not be believed ${ }^{11}$.

7 Maptuhah Maptuhah dan Juhji Juhji, "Pengaruh Perhatian Orangtua Dalam Pembelajaran Daring Terhadap Motivasi Belajar Peserta Didik Madrasah Tsanawiyah,” Attadrib: Jurnal Pendidikan Guru Madrasah Ibtidaiyah 4, no. 1 (22 Mei 2021): 25-34, https://jurnal.staidagresik.ac.id/index.php/attadrib/article/view/127.

8 Ahmad, Susanto. 2016. Teori Belajar dan Pembelajaran di SD. Bandung: Biomass Chem Eng

9 Hikmatul Mustaghfiroh, "REKONSTRUKSI FILSAFAT PENDIDIKAN ISLAM (MENGEMBALIKAN TUJUAN PENDIDIKAN ISLAM BERBASIS TUJUAN PENCIPTAAN DAN TUJUAN RISALAH)," Edukasia: Jurnal Penelitian Pendidikan Islam 10, no. 1 (27 Maret 2015), https://doi.org/10.21043/edukasia.v10i1.786.

${ }^{10}$ Muhammad Sarbini, "Pendidikan Keluarga Muslim Dalam Perspektif Fiqih Al-Qur`an,” Edukasi Islami: Jurnal Pendidikan Islam 4, no. 08 (25 Oktober 2017): 22, https://doi.org/10.30868/ei.v4i08.73; Mizanul Hasanah, "The Role of Parents in Children Memorizing the Qur'an in Middle School Based on the Amanatul Ummah Islamic Boarding School," Tafkir: Interdisciplinary Journal of Islamic Education 2, no. 2 (25 Juli 2021): 139-56, https://doi.org/10.31538/tijie.v2i2.43.

11 Alim, A. 2014. Sains dan Teknologi Islami. Bandung: Remaja Rosdakarya. 
The Islamic Values Civics module can provide students with a view from an early age, that natural science in particular is closely related to Islamic values. Teachers also want Islamic value modules to increase students' level of faith in Allah SWT and increase understanding of rights and obligations according to Islam. The Civics Education module with Islamic values is considered to be one of the appropriate learning resources used by elementary students in Helvetia sub-district, because until now there has been no Islamic value Civics module used.

The module is made with the aim of integrating Civics material with Islamic concepts, so a module that has Islamic values is needed, especially for high-grade elementary school students. The Islamic value module is considered to be one of the right choice of learning resources for students at this time, because it will assist students in learning the desired material and of course the material will be strengthened by the arguments of the Qur'an and Hadith relating to the material rights and learned obligations.

With the Islamic value module, students will get two advantages, namely still being able to learn the desired material easily and getting reinforcement about the material in an Islamic way. Making modules with Islamic values is expected to create a balance of knowledge that will be obtained by students. On the basis of this thought, the author is interested in studying and researching further about "Development of Islamic Value Civics Module on Rights and Obligations for High-Grade Elementary School Students in Central Helvetia District, Medan City".

\section{THEORY}

\section{Learning Module}

The module is a teaching material that is systematically arranged using language that is easily understood by students according to their level of knowledge and age so that they can learn on their own (independently) with minimal assistance or guidance from the teacher ${ }^{12}$. mastery of the material discussed in each module unit so that if they have mastered it, then they can proceed to the next level module unit. And conversely, if students have not been able to then they will be asked to repeat and relearn. Meanwhile, to assess whether or not a module is meaningful or not is determined by the ease with which the module is used by students in learning activities ${ }^{13}$. The preparation of making modules in learning activities has five objectives, namely: first: so that students can learn independently without, or, with the guidance of educators (which is minimal). Second: so that the role of educators is not too dominant and authoritarian in learning activities. Active, train students' honesty. Fourth, accommodate various levels and speed of student learning. For those whose learning speed is high, they can learn faster and complete the module quickly. And vice versa for those who are slow then welcome to repeat ${ }^{14}$.

The advantages obtained from learning with the application of the module are as follows: 1) increase the motivation of students, because each time they do a lesson task that is

12 Muhammad Rijal Fadli dan Ajat Sudrajat, "History Learning Module Based on Islamic Values on KH Hasyim Asy'ari's Jihad Resolution Material," Tadris: Jurnal Keguruan dan Ilmu Tarbiyah 5, no. 1 (2020): 65-75; Ummul Uslima, Chandra Ertikanto, dan Undang Rosidin, "Contextual Learning Module Based on Multiple Representations: The Influence on Students' Concept Understanding," Tadris: Jurnal Keguruan Dan Ilmu Tarbiyah 3, no. 1 (29 Juni 2018): 11-20, https://doi.org/10.24042/tadris.v3i1.2534.

13 Dharma, S. 2008. Penulisan Modul. Direktorat Tenaga Kependidikan , 3-5

14 Prastowo, A. 2012. Pengembangan Sumber Belajar. Yogyakarta: Pedagogia 
clearly defined and in accordance with their abilities; 2) after the evaluation, educators and students know correctly, in which modules students have succeeded and in which parts of the module they have not been successful; 3) students achieve results according to their abilities; 4) lesson materials are divided more evenly in one semester; and 5) education is more efficient, because learning materials are arranged according to academic level ${ }^{15}$.

\section{Islamic Values}

Al-Quran and Hadith explain how to do good. Both make the main basis for the source of Islamic values as a whole as a pattern of life and determine what is good and bad. The behavior of the prophet Muhammad is a role model for all mankind ${ }^{16}$. There is no discipline apart from Islamic ethics. The importance of the comparison between reason and revelation in determining moral values is open to debate. The provision of Islamic values in the learning process must of course go through ethics and systematic learning patterns following models, methods, and approaches as a form of teaching and learning strategy used so that the objectives can be achieved optimally. ${ }^{17}$ The cultivation of Islamic values in question is an action or way to instill valuable knowledge in the form of faith, worship and moral values based on the revelation of Allah SWT with the aim that students are able to practice their knowledge in everyday life properly and correctly with awareness without coercion. .

\section{Civic education}

Civics learning in elementary schools is intended as a teaching and learning process in order to help students learn well and shape Indonesian people as a whole in shaping the nation's character which is expected to lead to the creation of a society that places democracy in the life of the nation and state based on Pancasila, the Constitution. and norms prevailing in society. ${ }^{18}$ Civics subjects consist of the civics knowledge which covers the fields of politics, law, and morals. Dimensions of citizenship skills, include skills, participation in the life of the nation and state. The dimensions of civic values include, among others, self-confidence, commitment, mastery of religious values, noble norms and morals, values of justice, democracy, tolerance, individual freedom, freedom of speech, freedom of the press, freedom of association and assembly and protection of minority. Citizenship subject is an interdisciplinary field of study, meaning that citizenship science material is translated from several disciplines, including political science, state science, state administration, historical law, economics, morals, and philosophy. ${ }^{19}$

So it can be concluded that these are subjects that are used as a vehicle to develop and preserve noble and moral values rooted in the nation's culture, as well as form citizens who understand and are able to carry out their rights and obligations so that in the future they can become patriots who defend the nation and state.

\footnotetext{
${ }^{15}$ Santyasa, I Wayan. 2009. Metode Penelitian Pengembangan dan Teori Pengembangan Modul

16 Muhammad Qorib, 2020. Integrasi etika dan Moral. Yogyakarta: Blidung

17 Udaibah, W. 2013. Pengembangan Modul Kimia Anorganik. Terintegrasi Pendidikan Karakter pada Materi Kimia Koordinasi Tadris Kimia LAIN W alisongo Semarang. Semarang: IAIN Walisongo

18 Susanto, Ahmad. 2016. Teori Belajar \& Pembelajaran di Sekolah Dasar.Jakarta: Prenamedia Group.

${ }^{19}$ Depdiknas, Kurikulum Tingkat Satuan Pendidikan, Depsiknas, Jakarta, 2006.
} 


\section{Islamic Values Civics Module}

A module is a book written with the aim that students can learn independently without or with the guidance of a teacher. Through learning with this module, students are expected to be able to learn without any guidance from teachers or other educators. Islamic values are essentially a collection of life principles, teachings about how humans should live their lives in this world, which are interrelated with one another to form a unified whole that cannot be separated. Instilling Islamic values is the process of a person to provide an understanding of the characteristics that are important or useful for humanity based on the teachings of Allah revealed to the Prophet Muhammad in accordance with the Qur'an and Hadith $^{20}$

So this Islamic Value Civics module is a Civics Education book written with the aim that students can learn independently without or with teacher guidance about a material that is related to the teachings of Allah revealed to the Prophet Muhammad in accordance with the Qur'an and Hadith.

\section{METHOD}

This study uses a research and development model, which aims to develop learning products in the form of Islamic Values Civics Module. This study uses the Borg and Gall research model developed by Sugiyono which includes the stages of Potential and Problems, Data Collection, Module Design, Module Validation, Module Design Revision, Trial, product revision. $^{21}$

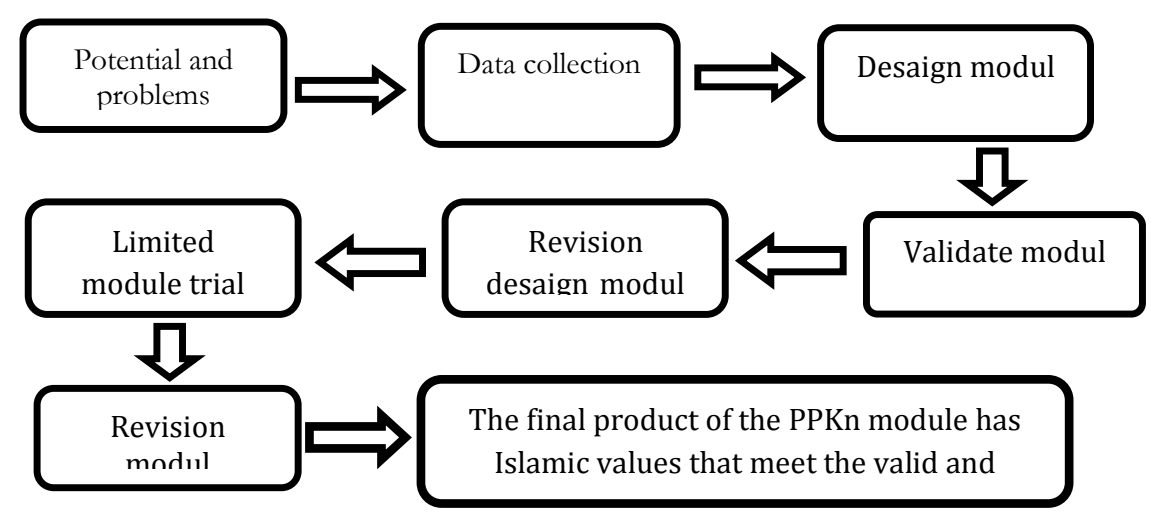

In module development research, the development stage is only up to the product revision step. The steps for developing the Islamic Value Civics module will be explained as follows:

20 Ichsan Ichsan, "Pendidikan Nilai Kejujuran Berbasis Kelas Di Madrasah Ibtidaiyah Negeri 1 Bantul Yogyakarta," Edukasia: Jurnal Penelitian Pendidikan Islam 14, no. 1 (24 Juni 2019): 49-70, https://doi.org/10.21043/edukasia.v14i1.3664; Ima Amaliah, Tasya Aspiranti, dan Pupung Purnamasari, "The Impact of the Values of Islamic Religiosity to Islamic Job Satisfaction in Tasikmalaya West Java, Indonesia, Industrial Centre," Procedia - Social and Behavioral Sciences, 2nd Global Conference on Business and Social Sciences (GCBSS-2015) on "Multidisciplinary Perspectives on Management and Society", 17- 18 September, 2015, Bali, Indonesia, 211 (25 November 2015): 984-91, https://doi.org/10.1016/j.sbspro.2015.11.131.

${ }^{21}$ Sugiyono, Metode penelitian Kuantitatif Kualitatif dan R\&D, Ed. 14 (Bandung: Alfabeta, 2014). 


\section{Potential and Problems}

In connection with the development of this module, the researcher provides added value that is not found in other teaching materials used by elementary school teachers in the Helvetia Tengah Village. This potential is to provide additional Islamic values in the developed Civics module. Giving Islamic values in this developed module provides added value to both teachers and students who use the module so that they can grow more gratitude to Allah SWT. and provide an introduction from an early age that especially the material in the content of Civics subjects has a lot to do with Islamic material. Therefore, the author makes a product in the form of a Civics module with Islamic values, especially on the material rights and obligations for high school graders.

\section{Data collection}

In developing the module that will be made, researchers need sources of information, including data obtained from literature studies and interview data for several teachers in the elementary school environment in Central Helvetia village.

\section{Module Design}

The module design stage is by preparing reference books related to the material rights and obligations and their relation to Islam as well as compiling a map of module needs, module design (formulation of basic competencies, design from the media side, preparation of material topics and determining the form of evaluation), preparation of assessment instrument designs.

\section{Design Validation}

The KDP module that is prepared will be validated by media and materials experts. The instrument used by the researcher to be given to the validator is a questionnaire instrument in the form of a rating scale. The indicators used were adopted from the National Education Standards Agency which were adapted to the needs of researchers.

\section{Module Design Revision}

The design of the PPKn module that has been validated and has received suggestions and directions by the two validators, will then be used as material for improvement. The revised PPKn module was then given to a high-class teacher, namely class V SD Ar-Rahman, Helvetia Tengah Village, to be assessed for validity and practicality.

\section{Product Trial}

The indicators used for the assessment of the validity and practicality of the module by Classroom teachers were also adopted from the National Education Standards Agency (BSNP). The repaired PPKn module was then given to the fifth grade high school teacher at SDS Ar-Rahman Fullday School in Helvetia Tengah Village. The results of the assessment and suggestions from this high-grade teacher will then be used to be improved and perfected for the better. The PPKn module that has been tested on high grade teachers and has received advice and direction by the teacher, will then be used as improvement material. The revised PPKn module was then given to high-grade elementary schools, namely $\mathrm{V}$ to assess its validity and practicality. 


\section{RESULT AND DISCUSION \\ Potential and Problems}

At this stage, interviews were conducted with several teachers in the Integrated Islamic Elementary School in Medan Helvetia District. The results of this interview that there are no teaching materials in the form of modules that are related to Islamic values. So far, the teaching materials used by teachers are limited to textbooks, worksheets, modules, CDs, pictures and other teaching aids. Some of the teaching materials used are generally not equipped with Islamic value materials that are relevant to the material being taught.

The researcher focuses on adding Islamic values to the Civics lessons taught with the aim that students know that the Civics subject matter is related to Islamic values in the form of verses in the Qur'an and Hadith, as well as fostering an attitude of responsibility and mutual respect for each other. man created by God.

\section{Data collection}

In developing the module that will be made, the researchers found sources of information, including data obtained from literature studies and interview data for several teachers in the SDS Ar-Rahman Elementary School, Muhammadiyah in Helvetia Tengah village. The data obtained through interviews with teachers showed that there was no PPKn module that linked learning materials with Islamic values. So far, the teaching materials used by teachers are just textbooks, LCDs, modules, pictures.

Desain Modul.

At this stage, the researcher designs the Islamic Values Civics module on rights and obligations. The design is made by adjusting the content of the module, the characteristics of elementary school children, the Civics learning material, namely the Rights and Obligations material.

Figure 1. Islamic-Based PPKN Mule
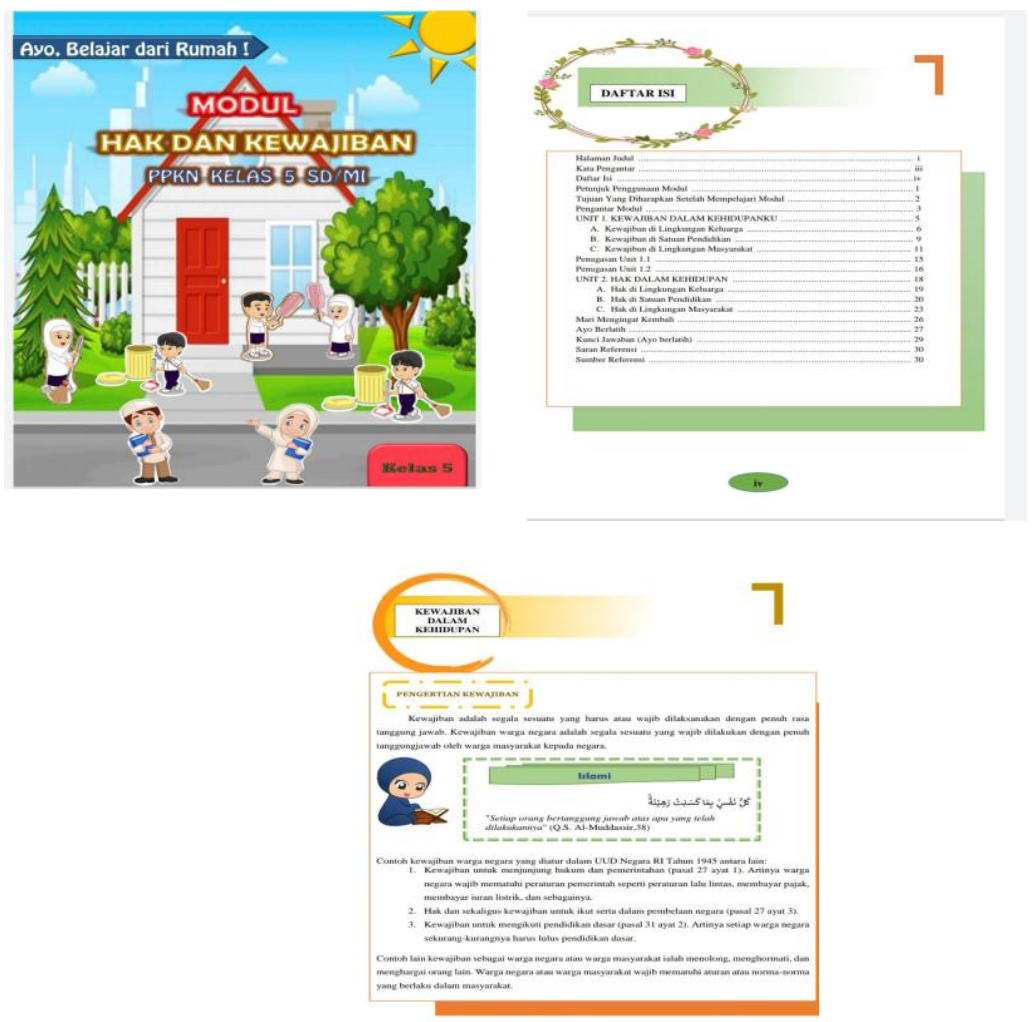


\section{Design Validation}

To obtain valid criteria, the researchers validated the experts, namely (1) Mrs. Azizah Thalib as a lecturer in Learning Media and ICT at Tadulako University (2) Mr. T. Ridwan, S.Pd as a teacher of Islam at SDS Ar-rahman. Based on the validation results from the experts, the final values were $96 \%$ and $86.76 \%$, respectively. This value is categorized as very valid. The categories of assessment from media and material experts are as follows:

Table 1. Material Expert Test

\begin{tabular}{|c|c|}
\hline Material Expert & Media Expert \\
\hline Material suitability & Module physical size \\
\hline Material accuracy & Module skin layout \\
\hline Supporting learning materials & $\begin{array}{l}\text { The letters used are attractive } \\
\text { and easy to read }\end{array}$ \\
\hline Material updates & Module cover illustration \\
\hline Islamic values & Layout consistency \\
\hline Presentation technique & Harmonious layout elements \\
\hline Material presentation support & Complete layout elements \\
\hline $\begin{array}{l}\text { In accordance with the } \\
\text { development of students }\end{array}$ & $\begin{array}{l}\text { Layout speeds up } \\
\text { understanding }\end{array}$ \\
\hline Communicative & $\begin{array}{l}\text { Simple book content } \\
\text { typography }\end{array}$ \\
\hline Dialogic and Interactive & Easy-to-read typography \\
\hline $\begin{array}{l}\text { Conformity with Indonesian } \\
\text { language rules }\end{array}$ & $\begin{array}{l}\text { Typography of the book } \\
\text { content makes it easier to } \\
\text { understand }\end{array}$ \\
\hline $\begin{array}{l}\text { Coherence and coherence in } \\
\text { the flow of thinking }\end{array}$ & Content illustration \\
\hline $\begin{array}{l}\text { Use of terms and } \\
\text { symbols/symbols }\end{array}$ & \\
\hline
\end{tabular}

\section{Design Revision}

From the results of the validation of the experts, there are several inputs that must be considered. The inputs are: (1) adding an example or illustration of the presentation of the material, and (2) adding a description of the material with daily examples. Lighter and simpler (3) adding more verses of the Koran according to the material.

\section{Product Trial}

Products that were declared valid by media experts and material experts were then tested on a limited group of 8 people. The subjects of this small group trial were fifth graders of SDS Ar-Rahman Fullday School. This trial was conducted to determine the practicality of the Civics module on rights and obligations seen from student responses. Student responses were obtained from the questionnaires they had filled out after learning. Learning is done online using the Google Meet application. The aspects of the assessment in the practicality test are (a) effective, (b) interactive, (c) interesting, (d) efficient, and (e) creative. The number of statements from the practicality questionnaire is 14 items. From the analysis of the results of 
the questionnaire obtained a value of $86.34 \%$ with a very practical category. The indicators for student responses to the module are as follows:

\begin{tabular}{|c|c|c|c|c|c|c|c|c|c|c|}
\hline \multirow[t]{2}{*}{ Variabel } & \multicolumn{8}{|c|}{ Responden } & \multirow{2}{*}{$\begin{array}{l}\text { Rata- } \\
\text { rata }\end{array}$} & \multirow{2}{*}{$\begin{array}{l}\text { Nilai } \\
\text { Perolehan }\end{array}$} \\
\hline & 1 & 2 & 3 & 4 & 5 & 6 & 7 & 8 & & \\
\hline $\mathrm{X}$ & 80,3 & 80 & 86 & 90 & 85,3 & 90,7 & 80,5 & 97,6 & 690,7 & 86,34 \\
\hline
\end{tabular}

\section{Product Revision}

After the product is tested on a limited group, the PPKn module with Islamic values can be identified its advantages and disadvantages. Subsequently, a product revision was made to the Islamic Value Civics module based on these advantages and disadvantages. However, in this study, because at the trial stage the limited group obtained very practical criteria, the Islamic Value Civics module could be used without the need for revision.

\section{CONCLUSSION}

Based on the results of the research that has been carried out, it can be concluded: 1) The Civics Education module has Islamic value. The material of rights and obligations developed has met the very valid criteria. This is evidenced by the average results of expert validation of $96 \%$ and $90 \%$ with very valid criteria. 2) The Civics module has Islamic values. The material of Rights and Obligations developed has met the practical criteria. This is evidenced by the results of the questionnaire from the small group trial. The score is $86.34 \%$ with very practical criteria.

\section{ACKNOWLEDGEMENT}

We as the TEAM implementing the Basic Research program would like to thank the Chancellor as the Leader of the University of Muhammadiyah North Sumatra and his staff as well as the Head of the Institute for Research and Community Service who have provided the opportunity to conduct research as a Tri Dharma Task of Higher Education through the APB University of Muhammadiyah North Sumatra in accordance with the letter Assignment Agreement for the Implementation of the Fundamental Research Program of the UMSU APB Fund for the 2021 Fiscal Year Number; 179 /II.3-AU/UMSU-LP2M/C/2021. In addition, we also thank the Principal of SDS Ar-Rahman Fullday School who has given permission to carry out research and all parties who have contributed suggestions and input to the research team.

\section{REFERENCES}

Ahmad, Susanto. 2016. Teori Belajar dan Pembelajaran di SD. Bandung: Biomass Chem Eng. Akrim,2021. Strategi Peningkatan Daya Minat Belajar Siswa.Yogyakarta: Pustaka Ilmu Al-Maragi, A. M. 1993. Tafsir Al-Maragi Juz VI. Semarang: Karya Toha Putra Alim, A. 2014. Sains dan Teknologi Islami. Bandung: Remaja Rosdakarya. Arifuddin. 2016. Konsep Integrasi Ilmu dalam Pandangan Ismail Raji Al-Faruqi. 
https://journal.iain-samarinda.ac.id/index.php/syamil/article/view/239

Dharma, S. 2008. Penulisan Modul. Direktorat Tenaga Kependidikan , 3-5

Izaak H. Weno. 2010. Pengembangan Model Modul Ipa Berbasis Problem Solving Method Berdasarkan Karakteristik Siswa Dalam Pembelajaran Di Smp/Mts. http://www.ccsenet.org/journal/index.php/ies/article/view/60170.

Izfi Muzari. 2016. Pengembangan Modul Ipa Terpadu Berbasis Sets pada Tema Makanan Sebat dan Tububku Meningkatkan Hasil Belajar. http://journal.uny.ac.id/index.php/cp/article/view/338

Mulyatiningsih, Endang. 2016. Pengembangan Model pembelajaran, Diunduh di bttp.staff.uny.ac.id/

Muhamad,Qorib. 2020. Integrasi Etika dan Moral. Yogyakarta: Blidung

Nasution. 2011. Berbagai Pendekatan dalam Proses Belajar Mengajar. Jakarta: Bumi Aksara.

Prastowo, A. 2012. Pengembangan Sumber Belajar. Yogyakarta: Pedagogia

Santyasa, I Wayan. 2009. Metode Penelitian Pengembangan dan Teori Pengembangan Modul.

Sugiyono. 2015. Metode Penelitian Pendidikan Pendekatan Kuantitatif, Kualitatif, dan R\&D. Bandung: Alfabeta

Udaibah, W. 2013. Pengembangan Modul Kimia Anorganik Terintegrasi Pendidikan Karakter pada Materi Kimia Koordinasi Tadris Kimia LAIN Walisongo Semarang. Semarang: IAIN Walisongo.

A. Rusdiana. Konsep Inovasi Pembelajaran. Bandung: Pustaka Setia, 2014.

Agustinus, Hermino. Manajemen Kurikulum Berbasis Karakter: Konsep, Pendekatan dan Aplikasi. Bandung: Alfabeta, 2014.

Almoayad, Fatmah, Afrah Almuwais, Samiah F. Alqabbani, dan Nada Benajiba. "Health Professional Students' Perceptions and Experiences of Remote Learning During the COVID-19 Pandemic." International Journal of Learning, Teaching and Educational Research 19, no. $\quad 8 \quad(30 \quad$ September 2020$)$. http://www.ijlter.org/index.php/ijlter/article/view/2621.

Amaliah, Ima, Tasya Aspiranti, dan Pupung Purnamasari. "The Impact of the Values of Islamic Religiosity to Islamic Job Satisfaction in Tasikmalaya West Java, Indonesia, Industrial Centre." Procedia - Social and Behavioral Sciences, 2nd Global Conference on Business and Social Sciences (GCBSS-2015) on "Multidisciplinary Perspectives on Management and Society", 17- 18 September, 2015, Bali, Indonesia, 211 (25 November 2015): 984-91. https://doi.org/10.1016/j.sbspro.2015.11.131.

Andres, Hayward P. "Active teaching to manage course difficulty and learning motivation." Journal of Further and Higher Education 43, no. 2 (7 Februari 2019): 220-35. https://doi.org/10.1080/0309877X.2017.1357073.

Bahrissalim, Bahrissalim, dan Fauzan Fauzan. "Evaluasi Kurikulum Pelatihan Dalam Meningkatkan Kompetensi Pedagogik Guru Pai Di Balai Diklat Keagamaan Jakarta." Edukasia : Jurnal Penelitian Pendidikan Islam 13, no. 1 (25 Juli 2018): 25-52. https://doi.org/10.21043/edukasia.v13i1.2779.

Fadli, Muhammad Rijal, dan Ajat Sudrajat. "History Learning Module Based on Islamic Values on KH Hasyim Asy'ari's Jihad Resolution Material." Tadris: Jurnal Keguruan dan Ilmu Tarbiyah 5, no. 1 (2020): 65-75.

Fahlevi, Mhd Reza, Asnil Aidah Ritonga, dan Wahyuddin Nur Nasution. "The Relevance of The Madrasah Aliyah Fiqh Package Book Published By The Indonesian Ministry of Religion With The 2013 Curriculum." Nazhruna: Jurnal Pendidikan Islam 4, no. 2 (19 Agustus 2021): 460-76. https://doi.org/10.31538/nzh.v4i2.1605.

Hasanah, Mizanul. "The Role of Parents in Children Memorizing the Qur'an in Middle School Based on the Amanatul Ummah Islamic Boarding School.” Tafkir: Interdisciplinary 
Journal of Islamic Education 2, no. 2 (25 Juli 2021): 139-56. https://doi.org/10.31538/tijie.v2i2.43.

Ichsan, Ichsan. "Pendidikan Nilai Kejujuran Berbasis Kelas Di Madrasah Ibtidaiyah Negeri 1 Bantul Yogyakarta." Edukasia : Jurnal Penelitian Pendidikan Islam 14, no. 1 (24 Juni 2019): 49-70. https://doi.org/10.21043/edukasia.v14i1.3664.

Maptuhah, Maptuhah, dan Juhji Juhji. "Pengaruh Perhatian Orangtua Dalam Pembelajaran

Daring Terhadap Motivasi Belajar Peserta Didik Madrasah Tsanawiyah." Attadrib: Jurnal Pendidikan Guru Madrasab Ibtidaiyah 4, no. 1 (22 Mei 2021): 25-34. https://jurnal.staidagresik.ac.id/index.php/attadrib/article/view/127.

Mustaghfiroh, Hikmatul. "REKONSTRUKSI FILSAFAT PENDIDIKAN ISLAM (MENGEMBALIKAN TUJUAN PENDIDIKAN ISLAM BERBASIS TUJUAN PENCIPTAAN DAN TUJUAN RISALAH)." Edukasia: Jurnal Penelitian Pendidikan Islam 10, no. 1 (27 Maret 2015). https://doi.org/10.21043/edukasia.v10i1.786.

Nasution, S. Berbagai pendekatan dalam proses belajar dan mengajar. Jakarta: PT. Bina Aksara, 2011.

Nilda, Nilda, Hifza Hifza, dan Ubabuddin Ubabuddin. "Peran Kepala Sekolah Sebagai Supervisor Dalam Meningkatkan Kinerja Guru Pendidikan Agama Islam Sekolah Dasar." Attadrib: Jurnal Pendidikan Guru Madrasah Ibtidaiyah 3, no. 1 (25 April 2020): 12 18. https://jurnal.staidagresik.ac.id/index.php/attadrib/article/view/160.

Rony, dan Siti Ainun Jariyah. "Urgensi Pendidikan Karakter Dalam Membentuk Akhlak Peserta Didik." Tafkir: Interdisciplinary Journal of Islamic Education 1, no. 1 (2020): 79-100. https://doi.org/10.31538/tijie.v1i1.18.

Sarbini, Muhammad. "Pendidikan Keluarga Muslim Dalam Perspektif Fiqih Al-Qur'an." Edukasi Islami: Jurnal Pendidikan Islam 4, no. 08 (25 Oktober 2017): 22. https://doi.org/10.30868/ei.v4i08.73.

Sugiyono. Metode penelitian Kuantitatif Kualitatif dan R\&D. Ed. 14. Bandung: Alfabeta, 2014.

Uslima, Ummul, Chandra Ertikanto, dan Undang Rosidin. "Contextual Learning Module Based on Multiple Representations: The Influence on Students' Concept Understanding." Tadris: Jurnal Keguruan Dan Ilmu Tarbiyah 3, no. 1 (29 Juni 2018): 1120. https://doi.org/10.24042/tadris.v3i1.2534. 